\title{
Pengembangan media pembelajaran berbasis PowToon pada perkuliahan Pendidikan Kewarganegaraan
}

\author{
Edwin Nurdiansyah $^{\text {a, }{ }^{*} \text {, Emil El Faisal }}{ }^{\text {b, }}$, Sulkipani ${ }^{\text {c, } 3}$ \\ ${ }^{a, b, c}$ Fakultas Keguruan dan Ilmu Pendidikan, Universitas Sriwijaya, Indralaya, Indonesia \\ ${ }^{1}$ edwin@unsri.ac.id*;2 emil_faisal@ymail.com; 3 sulkipani@fkip.unsri.ac.id \\ *korespondensi penulis
}

\begin{tabular}{|c|c|}
\hline Informasi artikel & ABSTRAK \\
\hline $\begin{array}{l}\text { Sejarah artikel: } \\
\text { Diterima }\end{array}$ & \multirow{4}{*}{$\begin{array}{l}\text { Penelitian ini bertujuan untuk mengembangkan media } \\
\text { pembelajaran berbasis PowToon pada perkuliahan Pendidikan } \\
\text { Kewarganegaraan di Universitas Sriwijaya. Data dikumpulkan } \\
\text { melalui teknik dokumentasi, angket, observasi dan tes. Teknik } \\
\text { analisis data yang digunakan ialah analisis data deskriptif } \\
\text { kuantitatif. Selain data hasil studi pendahuluan, data angket yang } \\
\text { berkaitan dengan validitas produk juga dianalisis dengan } \\
\text { menggunakan analisis deskriptif. Hasilnya, Media pembelajaran } \\
\text { berbasis PowToon ini valid sesuai pendapat dari para ahli, dan } \\
\text { praktis dalam penerapannya dan berefek potensial dalam } \\
\text { meningkatkan pemahaman mahasiswa terhadap materi } \\
\text { perkuliahan. }\end{array}$} \\
\hline : 02-03-2018 & \\
\hline Dipublikasikan & \\
\hline $\begin{array}{l}\text { Kata kunci: } \\
\text { Media pembelajaran } \\
\text { PowToon } \\
\text { Pendidikan Kewarganegaraan }\end{array}$ & \\
\hline
\end{tabular}

Keywords:

Instructional media

PowToon

Civic Education

\begin{abstract}
The development of PowToon-based instructional media in Civic Education. This research was aimed at developing instructional media based PowToon in Citizenship Education Course at Sriwijaya University. Data was collected through questionnaire, observation, and test. The collected data was analyzed quantitative description. The research reveals that instructional media based PowToon was valid according to both some experts, practicable, and has a potential effect to increase student understanding of course content.
\end{abstract}

\section{Pendahuluan}

Perkembangan teknologi informasi dan komunikasi telah merambah semua lini, tidak terkecuali dunia pendidikan. Dalam upaya meningkatkan mutu pendidikan salah satunya dapat ditempuh dengan memanfaatkan kecanggihan teknologi terutama dalam proses pembelajaran serta penyampaian materi. Para peneliti dari seluruh dunia telah mengeksplorasi program pembelajaran yang didukung oleh teknologi baru untuk meningkatkan kemampuan siswa dalam pengetahuan produktif dan kolaboratif (Zhang, 2010). Melalui hal tersebut diharapkan materi yang dipelajari dapat lebih dipahami dan bermakna bagi peserta didik. Media pembelajaran dapat turut serta memanfaatkan perkembangan teknologi informasi dan komunikasi. Media pembelajaran yang berbasis teknologi informasi dan komunikasi sebagai sumber belajar memiliki banyak manfaat yang bisa digunakan untuk mendukung penyajian materi pembelajaran. Namun demikian, pada abad 21 ini tidak ada upaya nyata yang dilakukan untuk memahami mengapa sebagian besar guru tidak siap untuk menggunakan teknologi yang muncul dalam pengajaran mereka (Lee \& Winzenried, 2009). Padalah, Kemp dan Dayton 
mengemukakan dampak positif penggunaan media diantaranya pembelajaran menjadi lebih efektif, interaktif, dan kualitas hasil belajar dapat ditingkatkan (Arsyad, 2011).

Selain bermanfaat untuk membuat materi pembelajaran tersampaikan dengan baik, media pembelajaran juga dapat membuat peserta didik menjadi lebih tertarik serta merespon dengan lebih positif sehingga mampu meningkatkan motivasi peserta didik dalam proses pembelajaran. Pemilihan media pembelajaran oleh guru tidak hanya mencerminkan minat pada hasil pembelajaran yang positif, tetapi juga kekhawatiran lain seperti menyenangkan bagi siswa, menjaga disiplin, memastikan siswa mendapatkan peningkatan pemahaman pengetahuan, dan mempersiapkan ujian (Martens \& Gainous, 2013). Dalam konteks Pendidikan Kewarganegaraan, media pembelajaran ini harus mampu untuk determine which methods and which combinations of methods do the best job of enhancing students' democratic capacity defined as their political knowledge, political efficacy, and intent to vote (Martens \& Gainous, 2013). Dengan demikian, media pembelajaran menjadi hal yang penting dalam mewujudkan proses pembelajaran yang efektif dan efisien sehingga tujuan pembelajaran dapat tercapai.

Pentingnya desain media pembelajaran yang terbaru pada era digital penting karena teknologi digital semakin memungkinkan dan mendorong jejaring sosial dan keterlibatan kolaboratif interaktif, termasuk mereka yang terlibat dan mempengaruhi pembelajaran (Davidson \& Goldberg, 2010, hal. 53). Teknologi dapat menyajikan peluang baru untuk pemodelan, simulasi, dan / atau menciptakan kembali lingkungan yang kompleks di mana siswa cenderung menemukan jati diri mereka (Bryer \& Seigler, 2012). Pada era digital seperti sekarang banyak aplikasi multimedia yang dapat dimanfaatkan sebagai media pembelajaran, misalnya penggunaan Camtasia, Edmodo, Moddle dan masih banyak lagi. Berbagai aplikasi multimedia tersebut menyediakan banyak macam pilihan gambar serta mampu memasukan video dan animasi di dalamnya sehingga media yang dihasilkan dapat memiliki lebih banyak variasi.

PowToon sebagai salah satu aplikasi multimedia yang dapat dijadikan media pembelajaran memiliki berbagai keunggulan misalnya memiliki fitur animasi yang sangat menarik diantaranya animasi tulisan tangan, animasi kartun dan efek transisi yang lebih hidup serta pengaturan lini masa yang sangat mudah. PowToon sangat cocok untuk dikembangkan sebagai media pembelajaran, selain menarik PowToon juga tidak perlu diinstal di komputer dikarenakan aplikasi ini dibuat secara online di laman www.PowToon.com. Meskipun dibuat secara online, namun hasilnya dapat dipergunakan secara offline baik dalam bentuk presentasi maupun dalam bentuk pdf.

Pembelajaran pendidikan kewarganegaraan haruslah dikemas sedemikian rupa misalnya dengan pemberian teladan dalam proses penanaman nilai, pemberian contoh nyata, serta menggunakan sumber belajar yang tepat termasuk penggunaan media belajar yang menarik dalam penyampaian materinya agar pembelajaran pendidikan kewarganegaraan mampu mencapai tujuan yang diharapkan. Keberhasilan pembelajaran Pendidikan Kewarganegaraan akan terwujud dalam bentuk peserta didik yang memiliki jati diri Pancasila serta mampu menghargai keberagaman. Mereka diharapkan memiliki kesadaran tentang hak dan kewajiban warga negara, serta mampu berbagai peran aktif dalam setiap bidang kehidupan termasuk menghasilkan solusi dari berbagai permasalahan negara.

Berdasarkan uraian tersebut, maka peneliti merasa sangat perlu untuk mengkaji mengenai pengembangan media pembelajaran pendidikan kewarganegaraan berbasis PowToon dalam bentuk penelitian pengembangan yang dilaksanakan melalui prosedur dan ketentuan ilmiah.

\section{Metode}

Artikel ini merupakan hasil dari jenis penelitian dan pengembangan (research and development) yang mengacu pada $\mathrm{R} \& \mathrm{D}$ 
Cycle Borg and Gall (Sukmadinata, 2007) dan diselaraskan dengan tujuan penelitian yang telah ditetapkan. Alur penelitian dimulai dengan pertama, studi pendahuluan untuk memperoleh informasi awal berkaitan dengan proses perkuliahan mata kuliah Pendidikan Kewarganegaraan. Kedua, tahapan pengembangan produk diawali dengan membahas hasil studi pendahuluan yang akan digunakan untuk uji coba media pembelajaran berbasis PowToon pada mata kuliah Pendidikan Kewarganegaraan. Ketiga, tahapan uji coba produk dilakukan dengan mengimplementasikan media pembelajaran yang telah dibuat dan dinyatakan valid oleh para ahli pada proses perkuliahan pendidikan kewarganegaraan.

\section{Hasil dan Pembahasan}

Studi pendahuluan merupakan proses untuk mendapatkan informasi awal dengan cara menganalisis fenomena dan hambatan yang dihadapi oleh mahasiswa dalam mengikuti perkuliahan Pendidikan Kewarganegaraan. Kegiatan ini dilakukan melalui diskusi dengan rekan sejawat pengampu mata kuliah Pendidikan Kewarganegaraan, serta melalui angket yang diberikan kepada mahasiswa yang pernah mendapatkan kuliah Pendidikan Kewarganegaraan terkait dengan analisis kebutuhan yang dilakukan. Dari hasil studi pendahuluan, ditarik kesimpulan bahwa mahasiswa memiliki motivasi yang kurang pada proses pembelajaran mata kuliah Pendidikan kewarganegaraan karena media yang digunakan dirasa kurang menarik bagi mahasiswa. Selain itu, sebagian besar pengajar hanya menggunakan media power point dalam proses pembelajarannya. Padahal, muatan materi PKn sangat penting diajarkan kepada mahasiswa dalam rangka membelajarkan serta membentuk karakter warga negara yang dibutuhkan di abad 21 . Kemampuan guru di abad 21 diantaranya menggunakan metode pembelajaran inovatif yang mengintegrasikan penggunaan teknologi yang mendukung pembelajaran, pendekatan berbasis masalah dan masalah serta keterampilan berpikir tingkat tinggi
(Partnership for 21st Century Learning, 2015). Penggunaan media yang konvensional dan tidak diperbaharui menyebabkan mahasiswa tidak lagi tertarik akan materi yang disampaikan.

Selanjutnya, setelah mengetahui beberapa kendala yang dihadapi dalam proses pembelajaran mata kuliah Pendidikan kewarganegaraan, peneliti melakukan analisis terhadap materi ajar yang akan dibuat dalam bentuk media pembelajaran. Pada tahap ini juga dilakukan diskusi dengan para pengajar kewarganegaraan lainnya. Adapun materi yang akan dikembangkan yaitu mengenai demokrasi. Hal tersebut penting dikarenakan dalam paradigma baru pembelajaran $\mathrm{PKn}$ yang sedang dilaksanakan saat ini salah satunya ialah membentuk warga negara yang cerdas, bertanggung jawab dan berpartisipasi aktif dalam setiap urusan kenegaraan, yang mana hal tersebut merupakan ciri dari negara demokratis.

Pada tahapan pengembangan produk yang dilakukan tim ialah menentukan beberapa materi yang akan disajikan dalam media pembelajaran, dikarenakan banyaknya materi yang terdapat dalam bahasan demokrasi maka tidak semua materi akan disajikan dalam media pembelajaran. Berdasarkan analisis yang telah dilakukan maka diperoleh beberapa materi yang akan dimasukan dalam media pembelajaran.

Media Pembelajaran yang dihasilkan oleh tim peneliti masih bersifat prototipe karena belum divalidasi oleh subjek validasi. Selanjutnya media Pembelajaran yang dihasilkan oleh tim peneliti diberikan kepada ahli untuk diteliti dan di validasi. Jika ditemukan kesalahan dan ada hal yang dirasa kurang tepat maka akan diadakan revisi sampai diperoleh hasil yang valid. Berdasarkan hasil validasi dari ahli materi, materi yang terdapat pada media pembelajaran ini dikategorikan valid dengan nilai validasi 92\%. Walaupun media pembelajaran sudah dinyatakan valid, namun validator menyarankan agar diberikan contoh yang lebih aktual berkaitan dengan pelaksanaan demokrasi di Indonesia. 
Selanjutnya, hasil uji validasi pertama yang dilakukan oleh validator media dapat dikategorikan cukup valid dengan nilai validasi $77,5 \%$. Hal tersebut mengindikasikan bahwa media pembelajaran yang dibuat perlu di revisi agar dapat dinyatakan valid. Beberapa poin saran dari ahli media ialah perlu dimasukan video dan gambar di dalam media pembelajaran tersebut. kemudian di media pembelajaran seharusnya poin-poin materi saja jangan membuat tulisan yang panjang. Selain itu juga untuk narasi suara yang ada di media pembelajaran diharuskan untuk diperbesar volumenya agar dapat terdengar secara jelas.

Setelah mendapatkan masukan dari ahli media, kemudian tim merevisi media pembelajaran tersebut. Setelah media pembelajaran tersebut dirasa oleh tim sudah sesuai dengan saran dari ahli media, maka selanjutnya dilakukan validasi yang kedua. Hasilnya media pembelajaran yang dibuat telah dinyatakan valid oleh ahli media dengan tingkat validasi $92,5 \%$ dan siap untuk diujicobakan.

Selanjutnya, hasil uji validasi pertama yang dilakukan oleh validator bahasa disimpulkan media pembelajaran ini dikategorikan cukup valid dengan nilai validasi $80 \%$. Hal itu menunjukkan jika media pembelajaran ini masih perlu sedikit perbaikan sesuai dengan komentar yang dibuat oleh ahli bahasa terutama pada penggunaan kata benda dan kata kerja yang sering tergabung dalam poin-poin materi demokrasi. Setelah diperbaiki, hasil uji validasi kedua yang dilakukan oleh validator bahasa dikategorikan valid dengan nilai validasi $85 \%$.

Berdasarkan hasil validasi pada materi, media, dan bahasa, maka dapat disimpulkan bahwa media pembelajaran ini memenuhi kriteria valid sehingga dapat diujicobakan di dalam pembelajaran di kelas untuk melihat efek penggunaannya berkaitan dengan motivasi dan hasil belajar. Validasi merupakan proses penting dalam pengembangan suatu produk. Dengan melalui tahap desain, produksi dan validasi dihasilkan produk yang terjamin kualitasnya dan dapat memenuhi fungsinya untuk mencapai kompetensi pembelajaran yang telah ditetapkan (Faisal \& Sulkipani, 2016; Warsita, 2008).

Pada tahap uji coba produk, data didapatkan dari mahasiswa sebagai bahan penyempurnaan media pembelajaran yang telah dibuat. Pelaksanaan uji coba yang dilakukan sampai pada penyusunan laporan kemajuan ini baru pada tahapan one to one, dan small group. Uji coba one to one dilakukan dengan mengambil tiga orang mahasiswa PPKn kampus Palembang yang mengikuti mata kuliah Pendidikan kewarganegaraan. Ketiga orang tersebut memiliki kemampuan yang berbeda dengan kategori tinggi, sedang dan rendah. Peneliti memberikan pembelajaran dengan menggunakan media pembelajaran yang telah dibuat. Pada akhir pembelajaran, ketiganya diberikan lembar penilaian yang harus mereka isi terkait dengan validitas media pembelajaran tersebut. Berdasarkan hasil review yang dilakukan oleh mahasiswa, maka diperoleh tanggapan sebesar 85,5 \% hal tersebut menunjukkan bahwa media pembelajaran yang dikembangkan oleh tim peneliti termasuk kategori valid. Namun demikian walaupun sudah valid ada beberapa poin yang menjadi masukan dari tahapan one to one ini yaitu: (1) kata-kata yang terdapat dalam video terlalu panjang; (2) timeline terlalu cepat; dan (3) suara narator yang terlalu kecil. Maka dari uji coba produk yang dilakukan di tahapan one to one dapat disimpulkan bahwa media pembelajaran yang dikembangkan oleh tim peneliti dinyatakan valid oleh mahasiswa meskipun ada beberapa masukan yang disampaikan oleh mereka. Selain itu, media pembelajaran ini juga mampu membuat mahasiswa aktif dalam proses pembelajaran hal itu terlihat dari hasil observasi yang dilakukan.

Uji coba small group tahap ini dilakukan dengan mengambil sembilan orang mahasiswa yang memiliki kemampuan berbeda, yaitu kategori rendah, tinggi dan sedang. Sembilan orang mahasiswa yang terlibat dalam uji coba tahap ini merupakan mahasiswa yang berbeda dari tahapan one to 
one. Sama seperti yang dilakukan pada tahapan one to one, peneliti memberikan pembelajaran dengan menggunakan media pembelajaran yang telah dibuat. Pada akhir pembelajaran, kesembilan mahasiswa diberikan lembar penilaian yang harus mereka isi terkait dengan validitas media pembelajaran tersebut. Berdasarkan hasil review yang dilakukan oleh mahasiswa pada tahapan uji coba kelompok kecil ini, maka diperoleh tanggapan sebesar 85,9 \%, hal tersebut menunjukkan bahwa media pembelajaran yang dikembangkan oleh tim peneliti termasuk kategori valid setelah diuji coba pada kelompok kecil, akan tetapi sebagian besar anggota kelompok kecil menilai pergantian antar frame pada media pembelajaran yang disajikan masih terlalu cepat sehingga adakalanya belum selesai terbaca sudah berpindah ke frame yang lain.

Berdasarkan hasil review dan observasi yang dilakukan pada uji coba kelompok kecil maka dapat disimpulkan bahwa media pembelajaran yang dikembangkan tim peneliti sudah memenuhi unsur validitas serta membuat mahasiswa berperan aktif selama proses pembelajaran Pendidikan Kewarganegaraan. Oleh karena itulah media pembelajaran yang dikembangkan ini akan dilanjutkan untuk uji coba lapangan dengan cara diujicobakan kepada seluruh mahasiswa di kelas. Tahapan ini dibuat menyerupai situasi pembelajaran yang sebenarnya dengan maksud jika produk tersebut telah dinilai layak maka dapat digunakan pada khalayak lainnya. Tetapi sebelum dilakukan uji coba lapangan akan dilakukan revisi terlebih dahulu sesuai dengan masukan yang ada pada tahapan sebelumnya yaitu small group.

Tahapan uji coba lapangan dimulai dengan pemberian tes awal (pretest) sebanyak 10 butir soal pilihan ganda kepada mahasiswa yang dijadikan objek penelitian, hal ini dimaksudkan untuk mengukur kemampuan awal mahasiswa berkaitan dengan materi demokrasi. Selanjutnya di akhir proses pembelajaran diadakan posttest. Skor dari tes tersebut disajikan pada tabel berikut,
Tabel 1. Skor Pretest dan Post test

\begin{tabular}{|c|c|c|c|}
\hline No & Nama & $\begin{array}{c}\text { Nilai Pre } \\
\text { Test }\end{array}$ & $\begin{array}{c}\text { Nilai Post } \\
\text { Test }\end{array}$ \\
\hline 1 & $\begin{array}{c}\text { Anang } \\
\text { Managsang }\end{array}$ & 6 & 8 \\
\hline 2 & $\begin{array}{c}\text { Rica } \\
\text { Anggraini }\end{array}$ & 6 & 7 \\
\hline 3 & $\begin{array}{c}\text { Melly } \\
\text { Saraswati }\end{array}$ & 6 & 7 \\
\hline 4 & Meriyanti Sari & - & - \\
\hline 5 & Yessy Farinda & 7 & 8 \\
\hline 6 & Anisah & 7 & 7 \\
\hline 7 & $\begin{array}{l}\text { Aulia Nova } \\
\text { Linda }\end{array}$ & 7 & 7 \\
\hline 8 & $\begin{array}{l}\text { Kevin } \\
\text { Yehezkiel } \\
\text { Juniko }\end{array}$ & 7 & 7 \\
\hline 9 & $\begin{array}{c}\text { Fathur Al } \\
\text { Athur }\end{array}$ & 7 & 8 \\
\hline 10 & $\begin{array}{c}\text { Ardea } \\
\text { Permata } \\
\text { Rahmadani }\end{array}$ & 6 & 7 \\
\hline 11 & Ista Tania & 5 & 7 \\
\hline 12 & $\begin{array}{c}\text { Riski } \\
\text { Kurniasih }\end{array}$ & 6 & 8 \\
\hline 13 & $\begin{array}{l}\text { Winda } \\
\text { Oktafiani }\end{array}$ & 7 & 8 \\
\hline 14 & $\begin{array}{c}\text { Ainun } \\
\text { Marhamah }\end{array}$ & 6 & 8 \\
\hline 15 & $\begin{array}{l}\text { Levi Utami } \\
\text { Putri }\end{array}$ & 6 & 8 \\
\hline 16 & $\begin{array}{c}\text { Dwi } \\
\text { Sucitahati }\end{array}$ & 7 & 9 \\
\hline 17 & $\begin{array}{c}\text { Santoso } \\
\text { Bagus } \\
\text { Izzulhaq }\end{array}$ & 8 & 9 \\
\hline 18 & $\begin{array}{l}\text { Anggun } \\
\text { Novtaria }\end{array}$ & 6 & 9 \\
\hline 19 & $\begin{array}{c}\text { Reni } \\
\text { Ermawati }\end{array}$ & 6 & 8 \\
\hline 20 & Rahma Dona & 5 & 7 \\
\hline 21 & $\begin{array}{l}\text { Aulida Dhea } \\
\text { Indhira }\end{array}$ & 6 & 8 \\
\hline 22 & Aizun Nabilla & 6 & 7 \\
\hline 23 & Melati Triyani & 5 & 7 \\
\hline 24 & Az Zhura & 7 & 8 \\
\hline 25 & $\begin{array}{c}\text { Nazomi } \\
\text { Wiratama }\end{array}$ & 7 & 9 \\
\hline 26 & $\begin{array}{l}\text { Nurlaila } \\
\text { Novita Putri } \\
\text { Total }\end{array}$ & 158 & 194 \\
\hline
\end{tabular}

Sumber: Data Primer Penelitian, 2017.

Berdasarkan tabel diatas, dapat dilihat rata-rata skor pretest sebesar 6,32 , sedangkan 
nilai posttest rata-ratanya sebesar 7,76. Maka dapat disimpulkan bahwa terdapat peningkatan sebesar 1,44 dan di dapatkan NGain sebesar 0,39 dengan kategori sedang. Hal tersebut menunjukkan bahwa media pembelajaran ini memiliki efek potensial terhadap peningkatan pemahaman mahasiswa mengenai materi perkuliahan. Pada tahapan uji coba lapangan juga menggunakan angket untuk melihat tanggapan mahasiswa mengenai media pembelajaran yang telah dikembangkan, hasilnya rata-rata tanggapan mahasiswa yang menggunakan media pembelajaran ini dikategorikan sangat baik dengan nilai sebesar $87,1 \%$. Menurut mahasiswa yang menggunakan media pembelajaran ini bahwasanya animasi dan video yang dalam media tersebut sangat membantu dalam mempelajari materi perkuliahan dikarenakan praktis dan menarik sehingga dapat membangkitkan minat. Untuk melihat keaktifan mahasiswa selama proses pembelajaran, digunakan juga teknik observasi yang hasilnya dapat dilihat pada tabel berikut,

Tabel 2. Hasil observasi tahap field evaluation

\begin{tabular}{|c|c|c|c|}
\hline No & Indikator & Jumlah & $\%$ \\
\hline 1. & $\begin{array}{c}\text { Mahasiswa antusias } \\
\text { memperhatikan } \\
\text { penjelasan dosen }\end{array}$ & 25 & 100 \\
\hline 2. & $\begin{array}{l}\text { Mahasiswa tidak } \\
\text { sibuk dengan } \\
\text { aktivitas diluar } \\
\text { proses pembelajaran }\end{array}$ & 25 & 100 \\
\hline 3. & $\begin{array}{c}\text { Mahasiswa } \\
\text { mengajukan } \\
\text { pertanyaan kepada } \\
\text { dosen }\end{array}$ & 5 & 20 \\
\hline 4. & $\begin{array}{c}\text { Mahasiswa } \\
\text { menanggapi } \\
\text { pertanyaan yang } \\
\text { diajukan dosen }\end{array}$ & 4 & 16 \\
\hline 5. & $\begin{array}{l}\text { Mahasiswa terlibat } \\
\text { aktif selama proses } \\
\text { pembelajaran }\end{array}$ & 20 & 80 \\
\hline & Total & & 316 \\
\hline & Rata-rata & & 63,2 \\
\hline
\end{tabular}

Sumber: Data Primer Penelitian, 2017.

Berdasarkan tabel hasil observasi diperoleh hasil sebesar $63,2 \%$ sehingga dapat disimpulkan bahwa keaktifan mahasiswa selama proses pembelajaran menggunakan media pembelajaran berbasis PowToon tergolong aktif.

Pengembangan media pembelajaran ini didasarkan untuk membantu pendidik menyampaikan materi pembelajarannya dan sekaligus juga membantu peserta didik dalam hal ini mahasiswa untuk dapat lebih memahami materi yang disampaikan. Melalui media pembelajaran juga diharapkan proses pembelajaran menjadi lebih menarik dan interaktif tidak lagi membosankan dan membuat jenuh apalagi jika pokok bahasan berisikan banyak muatan materinya karena media pembelajaran merupakan suatu media yang membawa pesan-pesan atau informasi yang bertujuan instruksional atau mengandung maksud-maksud pengajaran (Arsyad, 2011). Jika dalam aktivitas pembelajaran, media dapat didefinisikan sebagai sesuatu yang dapat membawa informasi dan pengetahuan dalam Interaksi yang berlangsung antara pendidik dan peserta didik, maka dapat disimpulkan bahwa media dalam pembelajaran memiliki peran sebagai pembawa pesan dan informasi yang berisikan instruksional pada interaksi antara pendidik dan peserta didik (Fathurrohman \& Sutikno, 2010; Purwanti, 2015).

Pembelajaran di era sekarang tidak mampu dilepaskan dengan perkembangan teknologi, maka proses pembelajaran yang dilakukan haruslah mengadaptasi teknologi agar dapat berdampak lebih luas. Teknologi memainkan peran penting dalam pendidikan siswa tanpa terkecuali. Memanfaatkan dan merancang teknologi ataupun media secara khusus dapat memberikan kontribusi yang besar terhadap pembelajaran yang efektif pada seluruh siswa dan dapat membantu mereka mencapai potensi tertinggi mereka terlepas dari kemampuan bawaan mereka (Smaldino, Lowther, Russell, \& Mims, 2008). Pengembangan Media pembelajaran berbasis aplikasi PowToon pada perkuliahan pendidikan kewarganegaraan dalam penelitian ini dilakukan dengan menyajikan materi-materi perkuliahan dalam bentuk audio visual disertai dengan template dan gambar-

6| Jurnal Civics: Media Kajian Kewarganegaraan 
gambar yang menarik dengan tujuan untuk meningkatkan perhatian peserta didik pada perkuliahan pendidikan kewarganegaraan. Sehingga dapat membuat mahasiswa yang mengikuti perkuliahan dapat termotivasi, seperti yang dikemukakan oleh Hamalik (2010) jika pemakaian media pembelajaran dalam proses belajar-mengajar dapat membangkitkan motivasi dan rangsangan kegiatan belajar, dan bahkan memengaruhi psikologis terhadap siswa. Kemudian Gafur (2009, hal. 8) mengemukakan jika dalam penyampaian pesan digunakan alat pemusat perhatian, hasil belajar akan meningkat. Maka dalam proses pembelajaran sangat diperlukan sebuah pemusat perhatian yang berisikan pesan pembelajaran yang mana hal tersebut salah satunya ialah media pembelajaran.

Pentingnya desain media pembelajaran yang terbaru pada era digital penting karena teknologi digital semakin memungkinkan dan mendorong jejaring sosial dan keterlibatan kolaboratif interaktif, termasuk mereka yang terlibat dan mempengaruhi pembelajaran (Davidson \& Goldberg, 2010, hal. 53). Teknologi dapat menyajikan peluang baru untuk pemodelan, simulasi, dan / atau menciptakan kembali lingkungan yang kompleks di mana siswa cenderung menemukan jati diri mereka (Bryer \& Seigler, 2012). Oleh karena itu diharapkan dengan adanya media pembelajaran yang berbasis teknologi pada perkuliahan PKn di Universitas Sriwijaya, maka akan dapat mencapai tujuan pembelajaran secara maksimal. Dengan lebih memahami materimateri yang ada pada pokok bahasan pendidikan kewarganegaraan, tujuan menciptakan masyarakat Indonesia yang baik sekaligus cerdas dapat terwujud.

\section{Simpulan}

Media pembelajaran PowToon yang dikembangkan ini praktis dan berefek potensial dalam meningkatkan pemahaman mengenai materi perkuliahan. Dengan demikian maka media pembelajaran yang dikembangkan ini layak digunakan dalam proses pembelajaran Pendidikan Kewarganegaraan di Universitas Sriwijaya.

\section{Referensi}

Arsyad, A. (2011). Media pembelajaran. Jakarta: Rineka Cipta.

Bryer, T. A., \& Seigler, D. (2012). Theoretical and instrumental rationales of student empowerment through social and web-based technologies. Journal of Public Affairs Education, 18(3), 429448.

Davidson, C. N., \& Goldberg, D. T. (2010). The future of thinking: Learning institutions in a digital age. Cambridge, Massachusetts London, England: The MIT Press.

Faisal, E. El, \& Sulkipani, S. (2016). Pengembangan bahan ajar berbasis muatan lokal pada mata kuliah Pendidikan Kewarganegaraan. Jurnal Civics: Media Kajian Kewarganegaraan, 13(2), 113. https://doi.org/10.21831/civics.v13i2. 12721

Fathurrohman, P., \& Sutikno, S. (2010). Strategi belajar mengajar. Bandung: Refika Aditama.

Gafur, A. (2009). Teknologi pembelajaran: konsep dan aplikasinya untuk pembelajaran Pendidikan Kewarganegaraan. Jurnal Civics: Media Kajian Kewarganegaraan, 6(1). Diambil dari https://journal.uny.ac.id/index.php/civ ics/article/view/5674/4900

Hamalik, O. (2010). Proses belajar mengajar. Jakarta: Bumi Aksara.

Lee, M., \& Winzenried, A. (2009). The use of instructional technology in schools. Victoria: ACER. Diambil dari wos:000274450300014

Martens, A. M., \& Gainous, J. (2013). Civic education and democratic capacity: How do teachers teach and what works? Social Science Quarterly, 94(4), 956-976. https://doi.org/10.1111/j.15406237.2012.00864.x

Partnership for 21st Century Learning. (2015). P21 partnership for 21st 
century learning. Partnership for 21 st Century Learning. Diambil dari http://www.p21.org/documents/P21_ Framework_Definitions.pdf

Purwanti, B. (2015). Pengembangan media video pembelajaran Matematika dengan model assure. Jurnal Kebijakan dan Pengembangan Pendidikan, 3(1), 42-47. Diambil dari http://ejournal.umm.ac.id/index.php/j mkpp/article/view/2194

Smaldino, S. E., Lowther, D. L., Russell, J. D., \& Mims, C. (2008). Instructional technology and media for learning. New Jersey: Pearson Merrill Prentice Hall Upper Saddle River.

Sukmadinata, N. S. (2007). Metode penelitian pendidikan. Bandung`: PT. Remaja Rosdakarya.

Warsita, B. (2008). Teknologi pembelajaran landasan dan aplikasinya. Jakarta: Rineka Cipta.

Zhang, J. (2010). Technology-supported learning innovation in cultural contexts. Educational Technology Research and Development, 58(2), 229-243. Diambil dari http://www.jstor.org/stable/40603158 